\title{
Close association between AI I8G single nucleotide polymorphism and opioid, alcohol, and nicotine dependence
}

This article was published in the following Dove Press journal:

Psychology Research and Behavior Management

8 May 2012

Number of times this article has been viewed

\author{
Shailendra Kapoor \\ Richmond,VA, USA
}

Correspondence: Shailendra Kapoor

2300 E Cary Street, Richmond,

VA 23223, USA

Email shailendrakapoor@yahoo.com
I read with great interest the article by Cosci et al in a recent issue of your journal. ${ }^{1}$ The article provides for highly interesting reading and is very thought-provoking. Interestingly, the past few years have seen the emergence of extensive data that establish a close association between the A118G single nucleotide polymorphism of the OPRM1 gene and opioid, alcohol, and nicotine dependence.

A higher threshold to pain has been observed in individuals with the $\mathrm{A} 118 \mathrm{G}$ variant. ${ }^{2}$ Not surprisingly, Tan et al and Kapur et al have demonstrated a close association between the $\mathrm{A} 118 \mathrm{G}$ variant and heroin dependence. ${ }^{3,4}$ Altered modulation of protein kinase A is responsible for this close association between the A118G variant of the OPRM1 gene and heroin dependency. ${ }^{5}$ A recent Japanese study has demonstrated that the presence of the $\mathrm{A} 118 \mathrm{G}$ polymorphism is associated with an increased risk of addiction to alcohol. ${ }^{6}$ Similarly, a recent Swedish study has demonstrated that the A118G variant is associated with an $11 \%$ risk of ethanol dependency. ${ }^{7}$ The treatment response to naltrexone in individuals with alcohol dependency varies greatly, depending on the presence or absence of the $\mathrm{A} 118 \mathrm{G}$ variant. ${ }^{8}$ In females, there is a strong association between nicotine reinforcement and the A118G haplotype. ${ }^{9}$

The above examples illustrate a close association between $\mathrm{A} 118 \mathrm{G}$ polymorphism and drug dependence. Hopefully, the coming years will see increased clinical application of this close association in identifying and effectively treating individuals with this polymorphism.

\section{Disclosure}

The author reports no conflicts of interest in this work.

\section{References}

1. Cosci F, Pistelli F, Lazzarini N, Carrozzi L. Nicotine dependence and psychological distress: outcomes and clinical implications in smoking cessation. Psychol Res Behav Manag. 2011;4:119-128.

2. Fillingim RB, Kaplan L, Staud R, et al. The A118G single nucleotide polymorphism of the mu-opioid receptor gene (OPRM1) is associated with pressure pain sensitivity in humans. J Pain. 2005;6:159-167.

3. Tan EC, Tan CH, Karupathivan U, Yap EP. Mu opioid receptor gene polymorphisms and heroin dependence in Asian populations. Neuroreport. 2003;14:569-572.

4. Kapur S, Sharad S, Singh RA, Gupta AK. A118g polymorphism in mu opioid receptor gene (OPRM1): association with opiate addiction in subjects of Indian origin. J Integr Neurosci. 2007;6:511-522.

5. Deb I, Chakraborty J, Gangopadhyay PK, Choudhury SR, Das S. Single-nucleotide polymorphism (A118G) in exon 1 of OPRM1 gene causes alteration in downstream signaling by mu-opioid receptor and may contribute to the genetic risk for addiction. J Neurochem. 2010;112:486-496. 
6. Nishizawa D, Han W, Hasegawa J, et al. Association of mu-opioid receptor gene polymorphism A118G with alcohol dependence in a Japanese population. Neuropsychobiology. 2006;53:137-141.

7. Bart G, Kreek MJ, Ott J, et al. Increased attributable risk related to a functional mu-opioid receptor gene polymorphism in association with alcohol dependence in central Sweden. Neuropsychopharmacology. 2005;30:417-422.
8. Ray LA, Hutchison KE. Effects of naltrexone on alcohol sensitivity and genetic moderators of medication response: a double-blind placebocontrolled study. Arch Gen Psychiatry. 2007;64:1069-1077.

9. Ray R, Jepson C, Patterson F, et al. Association of OPRM1 A118G variant with the relative reinforcing value of nicotine. Psychopharmacology (Berl). 2006;188:355-363. 


\section{Authors' response}

\section{Fiammetta Cosci \\ Giuly Bertoli}

Department of Psychology, University

of Florence, Firenze, Italy

Correspondence: Fiammetta Cosci

Department of Psychology, University of Florence,

via di San Salvi 12, 50134 Firenze, Italy

Email fiammetta.cosci@unifi.it

We thank Dr Kapoor for appreciating our review on nicotine dependence and psychological distress, and having taken it as a cue to reflect on the possible association between the A118G single nucleotide polymorphism of the OPRM1 gene and drug dependence. The literature offers several sets of data on this issue but, unfortunately, only a small number of studies have focused on nicotine dependence. For instant, Ray et al recently noted that human mu opioid receptor (OPRM1 A118G) polymorphism is associated with brain $\mu$ opioid receptor binding in smokers. ${ }^{1}$ Further, Falcone et al found increased availability of the $\mu$ opioid receptor in the amygdala of smokers that could be contributory, emphasizing the motivation to smoke to obtain negative affective relief. ${ }^{2}$

Of course, we really hope that future investigations will clarify the possible association between smoking and genes, and as a further step, lead to the development of novel therapeutics. However, it is noteworthy that we are constantly reminded that genetics will transform and improve our practice, but nothing has really come in the past two decades. ${ }^{3,4}$ Thus, psychopathology ${ }^{5}$ and clinical judgment, ${ }^{6}$ still underappreciated as scientific tools but commonly used in clinical practice, can be a valid alternative approach to make the correct diagnosis and choose a tailored treatment for drug dependence, in particular for nicotine dependence. Indeed, good organization of clinical information (encompassing, eg, psychological distress and psychological well being), the use of a transfer station with repeated evaluations instead of diagnostic endpoints, ${ }^{7}$ and staging methods ${ }^{8}$ may guide assessment, treatment choice, and planning of followup visits or interventions. ${ }^{7}$

\section{Disclosure}

The authors report no conflicts of interest in this work.

\section{References}

1. Ray R, Ruparel K, Newberg A, et al. Human mu opioid receptor (OPRM1 A118G) polymorphism is associated with brain mu-opioid receptor binding potential in smokers. Proc Natl Acad Sci USA. 2011;108:9268-9273.

2. Falcone M, Gold AB, Wileyto EP, et al. $\mu$-Opioid receptor availability in the amygdala is associated with smoking for negative affect relief Psychopharmacology. March 3, 2012. [Epub ahead of print].

3. Fava GA. The clinical factor. Psychother Psychosom. 2011;80:1-3.

4. Balon R. Clinical factor 2010. Psychother Psychosom. 2011;80: 195-198.

5. Lipowski ZJ. Psychopathology as a science: its scope and tasks. Compr Psychiatry. 1966;7:175-182.

6. Faust D, Nurcombe B. Improving the accuracy of clinical judgment. Psychiatry. 1989;52:197-208.

7. Fava GA, Rafanelli C, Tomba E. The clinical process in psychiatry: a clinimetric approach. J Clin Psychiatry. 2012;73:177-184.

8. Cosci F, Fava GA. New clinical strategies of assessment of comorbidity associated with substance use disorders. Clin Psychol Rev. 2011;31:418-427.

\section{Publish your work in this journal}

Psychology Research and Behavior Management is an international, peerreviewed, open access journal focusing on the science of psychology and its application in behavior management to develop improved outcomes in the clinical, educational, sports and business arenas. Specific topics covered include: Neuroscience, memory \& decision making; Behavior

\section{Dovepress}

modification \& management; Clinical applications; Business \& sports performance management; Social and developmental studies; Animal studies. The manuscript management system is completely online and includes a quick and fair peer-review system. Visit http://www.dovepress. com/testimonials.php to read real quotes from published authors. 